\title{
A comparison of the autecology of two seed-taking ant genera, Rhytidoponera and Melophorus
}

Jonathan D Majer Aaron D Gove Stan Sochacki Philip Searle Christopher Portlock

\begin{abstract}
Members of the genus Rhytidoponera and, to a lesser extent, certain Melophorus spp. are keystone mutualists for the dispersal of seeds in the southwest of Western Australia, with important ramifications for the ecology and speciation of plants in this biodiversity hotspot. For this reason, it is important to understand the autecology of the relevant ant species and the way in which they interact with plant seeds. This paper addresses key aspects of the ecology of three such ant species, Rhytidoponera violacea (Forel), $R$. inornata Crawley and Melophorus turneri perthensis Wheeler. Data are presented on their geographic distribution, seasonality of foraging, diurnal activity, response to fire, nest site preference, nest structure, colony size, feeding habits, foraging response to seed availability, and seedling emergence from nests. The role of all three species as seed dispersers is confirmed, and all three species have ecologies that are well-suited for dispersal and survival of native plant seeds. Preservation of this interaction is important for the conservation of plants, and it is fortuitous that all three species are able to survive disturbance and return to rehabilitated areas. However, the smaller $R$. inornata, and to a lesser extent, the larger $R$. violacea, are vulnerable to invasive ant (Pheidole megacephala (Fabricius) incursions. M. turneri perthensis is able to coexist with the invasive ant unless this is at high densities, probably as a result of its ability to forage during high temperatures when the invasive species is inactive.
\end{abstract}

Keywords Ant autecology . Myrmecochory . Seed . Seedling . Nest . Foraging . Distribution . Fire

Jonathan D Majer

Curtin Institute for Biodiversity and Climate, Department of Environment and Agriculture, Curtin University, PO Box U1987, Perth, WA 6845, Australia

e-mail: J.Majer@curtin.edu.au

Jonathan D Majer . Aaron D Gove . Stan Sochacki . Philip Searle

Department of Environment and Agriculture, Curtin University, PO Box U1987, Perth, WA 6845, Australia

Christopher Portlock

Shire of Serpentine, Jarrahdale, WA 6124, Australia

\section{Introduction}


Although the advent of insect pollination of flowers is known to have been a driver of angiosperm diversification, seed dispersal by organisms such as ants has also been implicated, but not proven. Seed dispersal by ants (myrmecochory) may drive diversification by reducing extinction, hence providing selective advantages to plants, and by increasing speciation as a result of geographical isolation associated with extremely limited dispersal distances (Dunn et al., 2008). Lengyel et al. (2009a, b) tested the hypothesis that myrmecochory leads to higher diversification rates in angiosperm plants by comparing richness of plants in sister groups that were ant-dispersed or dispersed by other means. They found that ant-dispersed lineages contained on average more than twice as many species as did their non-myrmecochorous sister groups, suggesting that myrmecochory is a key evolutionary innovation and a globally important driver of plant diversity.

The Australasian ant genus Rhytidoponera is recognised as a keystone mutualist for dispersal of myrmecochorous plant species in Australia (Gove et al., 2007). Members of a second genus, Melophorus, are also important in this regard (Briese and Macauley, 1981; Majer, 1982). Rhytidoponera are common throughout Australia, occurring in all habitats. They are generalised foragers and tend to forage at night or during cooler parts of the day (Ward, 1981; Nielsen, 1997). The genus Melophorus is also found throughout Australia, and is most abundant and diverse in arid regions (Andersen, 2007). Members of the genus are capable of foraging at very high temperatures (Christian and Morton, 1992; Hoffmann, 1998).

In view of their pivotal role in seed dynamics, and the fact that the southwest of Australia is a plant biodiversity hotspot (Myers et al., 2000; Hopper and Gioia, 2004), we revisit a dataset and compare the autecology and role in seed-taking of two southwest Australian species of Rhytidoponera with one species of Melophorus. The species concerned are Rhytidoponera violacea (Forel), $R$. inornata Crawley and Melophorus turneri perthensis Wheeler, which are the most prominent species involved in myrmecochorous relationships in southwestern Australia (Majer, 1982; Gove et al., 2007). M. turneri perthensis has been referred to as Melophorus sp. 1 (ANIC) in earlier papers.

We examine how Rhytidoponera and Melophorus behave in terms of their phenology, response to fire and interactions with myrmecochorous seed. Within this context, we examine nest structure, nest location, diurnal and seasonal variation in activity, the effect of fire and the species' associations with seed-fall and seed-collection. We also consider this in the context of habitat disturbance and subsequent restoration, and also in terms of invasive ant incursions. In doing this, we hope to obtain greater insight into the relationship between these three important seed takers, the seeds with which they interact, and how this important interaction might be impacted by human disturbance.

\section{Methods}

Geographic range of species 
The distribution records of $R$. violacea, $R$ inornata and $M$. turneri perthensis, obtained by searching records of the CSIRO Entomology Biolink® database, are shown in Figures 1 $\mathrm{a}, \mathrm{b}$, and c, respectively. These records are only for collections where specimens have been retained in the Curtin University or CSIRO - ANIC collections. As such, they are suggestive rather than complete representations of the complete range of these three species. Rhytidoponera inornata occupies coastal areas of the southwest region of the State, and is also distributed along the south coast, at least as far as Esperance. By contrast, $R$. violacea is widely distributed throughout most of the State, being present in most regions except for the northern part of the Kimberley. M. turneri perthensis is common in the southwest of WA and extends through the central Goldfields into the northern Pilbara region. It does not seem to extend into the arid interior of the State. The taxonomy of Melophorus is currently under review, so this distribution may ultimately represent more than one species.

Sites and general sampling techniques

Ant sampling was conducted between February 1976 and April 1979 at seven sites in the southwest of Western Australia (Table 1, Figure 2.). The Dwellingup, Karragullen and Manjimup sites are on the Darling Plateau, with laterite soils, while the Perth and Yalgorup sites are on the Swan Coastal Plain, which has sandy soil. Ant seasonality was assessed at six of the sites (not at Yalgorup) using a procedure described in detail in Koch and Majer (1980). At five of the sites a 6 x 6 grid of $18 \mathrm{~mm}$ internal diameter pitfall traps, $3 \mathrm{~m}$ apart, was left open for one week; while at Karragullen a $5 \times 4$ grid of $54 \mathrm{~mm}$ internal diameter traps, $5 \mathrm{~m}$ apart, was used. Further details of the sites are given in Koch and Majer (1980) and Majer (1984). The six locations were repeatedly sampled on no less than a monthly basis for a year or more (see Table 1 for period details). Additionally, a range of measurements and observations were performed on colonies and nests at the Karragullen and Dwellingup sites, and also at Yalgorup National Park.

\section{Seasonality of foraging}

We tested for a temporal correlation of Rhytidoponera and Melophorus activity in each of the six pitfall trap locations using Spearman's rank correlation. We then asked whether ant activity for each species varied seasonally. In order to create replicated samples, we matched up each month of sampling from the six locations (no matter in which year this month occurred). We then performed an ANOVA to determine whether ant activity varied significantly amongst months. We performed the tests separately for the three ant species.

\section{Diurnal activity}

At the Karragullen site, nest entrances were observed for 3 minutes, every hour for 24 hours and the number of individuals leaving the nest was quantified. This was done for all three species in three seasons: Summer - 22 Feb 1978; Winter - 25 May 1978; Spring 
- 31 Aug 1978. The response of these species to daily environmental variation was compared.

Response to fire

Four of the six sites were subjected to controlled burns (See Table 1). In each case a matched control (unburnt) plot of pitfall traps was sampled during the same period as the burnt plot, before and after the burn.

Analysis was performed separately for each species. We used a Before-After Control Impact (BACI) design, with each of the four sites representing a replicate. Within each site we calculated a mean value of ant abundance across sample periods for the Before-After x Control-impact combination. After-fire activity was based on 12 months of post-fire data. We did not treat each sample period within each combination as a replicate, as in one case we only had one sample period prior to the burn. We tested for an effect of the burn on ant abundance by examining the interaction term.

Nesting preference

Nest densities were quantified for $M$. turneri perthensis and $R$. inornata in $1 \mathrm{~m}$ grid cells of a 0.04 ha plot at Dwellingup; nests of $R$. violacea were not found in this plot. These densities were then compared to the frequency of ground-cover and overstorey shade categories at the site. Nest location preference for each species was tested separately using a Chi square test.

Nest structure and depth

The structure and depth of nests was assessed by lead casting. Lead was liquefied in a crucible and poured into nest entrances, then allowed to cool and solidify. The resulting caste was dug up, cleaned in water, photographed and measured, thus enabling structure and depth to be obtained. Five nests each of $R$. inornata, $R$. violacea and $M$. turneri perthensis were assessed from laterite at Karragullen or Dwellingup and a further five nests of $M$. turneri perthensis were assessed from sands at Yalgorup.

\section{Colony size}

During the peak summer activity period, five nests each of $R$. inornata and $R$. violacea were excavated from the Karragullen site and the soil was passed through a stack of sieves of progressively decreasing mesh size. Ants were separated from the soil by floatation, and counted. We lacked comparable data for M. turneri perthensis, so five nests of this species were sampled from the sand plain in Perth during the summer of 2009.

Feeding habits 
At Karragullen, five nests of each species were observed for 30-minute periods monthly between April 1978 and April 1979. All ants observed carrying food items were collected and the food was removed and identified to the best level possible.

Diet composition was further measured at Karragullen by scraping the soil middens from around nest entrances of the three species and separating the organic material from the soil by floatation in saturated magnesium sulphate. The seeds and arthropod fragments from this organic material were identified and counted.

Foraging response to seed availability

During the period Feb 1978 - April 1979, plant flowering phenology was monitored monthly at the Karragullen site. In each month, the species of flowering plants were recorded over a 1.2 ha area (see Majer, 1980a for further details). We divided the plant species into myrmecochores and non-myrmecochores and tested for correlations between ant activity and species richness of flowering myrmecochores in each month. As we were particularly interested in the correlation between ant activity and myrmecochore seedrain, we tested for a correlation between the two with various lag periods $(1,2,3$ and 4 months). We tested for the correlation using data for the three ant species separately. We also tested for variation in flowering phenology of myrmecochore and nonmyrmecochore plant species using the statistical technique described by Estabrook et al. (1982; see also Guitián and Garrido, 2006).

Seedling emergence from nests

Since many local plant species require fire to stimulate germination, the effects of fire were simulated over $10 \mathrm{R}$. inornata and $15 \mathrm{M}$. turneri perthensis nests near Dwellingup, during winter, 1979. Fire was simulated by inverting a Pyrox Schwank ${ }^{\circledR}$ infra-red gas heater over the nest and heating the soil to $100^{\circ} \mathrm{C}$ at $2 \mathrm{~cm}$ depth for $30 \mathrm{~min}$. An equivalent area of bare soil $1 \mathrm{~m}$ from the nest was also heated and a further set of unheated nests and nearby soil were also marked out. Seedling emergence was recorded in the marked out areas over the next 2 months.

\section{Results}

Seasonality of foraging

Across the periods sampled, Rhytidoponera spp. and Melophorus monthly activity was positively correlated in only two of the six locations, Karragullen and Reabold Hill $(P=$ $0.025, P<0.001$, Rho $=0.576 \& 0.868$ respectively).

Melophorus turneri perthensis showed significant seasonal variation in activity $\left(\mathrm{F}_{11,70}=4.462, P<0.001\right.$, Figure $\left.3 \mathrm{c}\right)$. Both Rhytidoponera spp. followed a similar seasonal pattern in activity (Figures $3 \mathrm{a} \& \mathrm{~b}$ ), but this was not significant for $R$. violacea $\left(\mathrm{F}_{11,59}=\right.$ $1.306, P=0.244)$ or $R$. inornata $\left(\mathrm{F}_{11,59}=0.846, P=0.596\right.$, $)$. Melophorus turneri perthensis exhibited a more pronounced increase in activity during the spring-summer months (November to February). Rhytidoponera also demonstrated a peak in activity during January to February, but not to the same extent. Melophorus turneri perthensis exhibited 
a complete lack of activity during winter months, while both Rhytidoponera spp. maintained low-level activity during this period.

On average, across all locations and all sampling periods, Rhytidoponera spp. was 1.4 times more active than Melophorus .

Diurnal activity

All ant species were most active in the summer months (Figures $4 \mathrm{a}, \mathrm{b} \& \mathrm{c}$ ). While Rhytidoponera spp. activity peaked in the morning (Figures $4 \mathrm{a} \& \mathrm{~b}$ ), approximately after sunrise, Melophorus activity peaked during early afternoon (Figure 4c) - generally the warmest part of the day. No Melophorus activity outside of nests was recorded during the winter and spring observation periods. During winter, Rhytidoponera (inornata especially) activity peaked during the early afternoon, again in the warmest part of the day.

Response to fire

Rhytidoponera violacea and $R$. inornata demonstrated no clear response to fire. Rhytidoponera violacea maintained activity after the burns (Figure 5a, $\mathrm{F}_{1,12}=0.399, P=$ 0.54). Rhytidoponera inornata may have declined in activity after the burns, but so did activity in the unburnt plot (Figure $5 \mathrm{~b}, \mathrm{~F}_{1,12}=0.117, P=0.738$ ). The effect of burning on Rhytidoponera spp. activity was therefore inconsequential.

In the control plots there were as many M. turneri perthensis individuals active after the burns as there were before the burns (Figure 5c). In the burnt plots, however, activity decreased, with 1.7 times as many individuals active before the burns as compared to after the burn. This direction of change was only apparent in three of four sites (in the fourth site, activity increased by $>100 \%$ after the burn) and there was not a significant treatment $\mathrm{x}$ time effect $\left(\mathrm{F}_{1,12}=0.518, P=0.485\right)$. Therefore, although fire may decrease Melophorus activity, this pattern is not uniform.

Nesting preference

We located 27 nests each of $R$. inornata and $M$. turneri perthensis, representing nest densities of 675 per ha for each species. We were unable to locate sufficient nests of $R$. violacea to examine densities or nest-habitat relationships, although unpublished observations elsewhere suggest that similar nest densities to $R$. inornata can be achieved. Rhytidoponera inornata did not demonstrate a significant nest site preference (ground cover, $\chi^{2}=0.73$, Figure $6 \mathrm{a}$; top cover, $\chi^{2}=3.67$, Figure $6 \mathrm{~b}$ ). In contrast, M. turneri perthensis had a significant nest site preference for sites with a low ground cover $\left(\chi^{2}=\right.$ $10.13, P<0.01$, Figure $6 \mathrm{c})$ and low overstorey shade $\left(\chi^{2}=7.35, P<0.05\right.$, Figure $\left.6 \mathrm{~d}\right)$.

Nest structure and depth

Rhytidoponera violacea nests were, on average, $22.2 \mathrm{~cm}$ deep (Table 2) and were often associated with buried woody material. Structurally, nests tended to comprise a broad vertical channel, which often spiralled around a live or dead woody taproot (Figure 7a). 
$R$. inornata nests were of a similar depth $($ mean $=25.2 \mathrm{~cm})$ but the channels of the nest were much finer than those of the other Rhytidoponera sp., and led off into smaller side branches (Figure 7b). Melophorus turneri perthensis nests were of a rather different structure, comprising a vertical channel with a series of side galleries at reasonably regular intervals (Figure 7c). Seeds were frequently observed embedded in the lead from these galleries. Melophorus turneri perthensis nests from the laterite were significantly more shallow $($ mean $=12.7 \mathrm{~cm})$ than nests in the sandy soil at Yalgorup $($ mean $=21.7$ $\mathrm{cm})\left(\mathrm{F}_{3,34}=5.37 \mathrm{P}=0.004\right)$ (Table 2).

\section{Colony size}

The number of workers per nest of $R$. violacea and $R$. inornata was small and fairly similar (mean $=173.2$ and 197.6 workers respectively), and sizeable numbers of alates were found to be present (Table 3). Numbers of workers in the M. turneri perthensis nest were also fairly small $($ mean $=230.4)$ and no alates were found.

Feeding habits

Rhytidoponera inornata workers were not observed carrying food frequently enough to make any generalisations about food preferences. Rhytidoponera violacea was observed carrying invertebrate prey or carrion throughout the year and seeds were present in their forage during March and April, comprising 6.3\% of dietary observations from the entire observation period (Table 4). M. turneri perthensis ceased foraging during the cooler months, but was observed carrying seed from November through to May, with this component comprising $29.1 \%$ of forage. The rest comprised miscellaneous plant fragments (25.3\%) and invertebrates (54.6\%) (Table 4). Taking account of the full observation period, $M$. turneri perthensis carried 4.6 times as many seeds as $R$. violacea.

We were able to obtain data from middens for all three species and all exhibited an omnivorous diet of arthropods and seeds, although we cannot discount the possibility that they might also feed on nectar. The latter is most unlikely, as none of these species ascend trees or shrubs. Based on nest middens, M. turneri perthensis was the most reliant on seeds (49.3\%), followed by $R$. violacea (37.6\%), and R. inornata (8.0\%) (see Table 5 for details).

Foraging response to seed availability

Flowering phenologies of myrmecochorous and non-myrmecochorous plant species were very similar $\left(\mathrm{D}_{\text {observed }}=0.216, \mathrm{D}_{\mathrm{p}=0.05}=0.309\right)$, with peaks in Sept-Oct. The best regression models relating ant activity to myrmecochore flowering were found after a four month lag for both $M$. turneri perthensis $\left(\mathrm{R}^{2}=0.572\right.$; Figure $\left.8 \mathrm{c}\right)$ and $R$. violacea $\left(\mathrm{R}^{2}=0.692\right.$; Figure 8a). In none of the lag periods was the activity of $R$. inornata positively correlated with myrmecochore flowering, and the best correlation was found after a one month lag $\left(\mathrm{R}^{2}=0.232\right.$; Figure $\left.8 \mathrm{c}\right)$.

Seedling emergence from nests 
Some seedlings emerged from the directly heated rectangle surrounding the nest opening of both $R$. inornata and M. turneri perthensis. However, many seedlings emerged from a $3 \mathrm{~cm}$ boundary outside of the rectangle, presumably because the lateral conduction of heat provided conditions that were optimal for these plant species (Figure 9). For both ant species, the number of seedlings emerging was much higher around ant nests, it being almost non-existent elsewhere. Furthermore, the number of seedlings emerging was much higher around the heated nests than the unheated counterparts (Figures 10a and b). Melophorus turneri perthensis demonstrated a significant species x treatment interaction, with Trymalium ledifolium emerging in higher densities from heated nests than other treatments $\left(\mathrm{F}_{3,112}=3.9, \mathrm{P}=0.011\right)$. Acacia pulchella was not affected by treatments. A similar pattern was evident in $R$. inornata nests $\left(\mathrm{F}_{3,72}=2.3, \mathrm{P}=0.082\right)$.

\section{Discussion}

The findings presented here, along with those from an earlier paper which examined the fate of seeds taken by these three ant species (Majer, 1982), indicate a close association between the biology of these ant species and their potential to disperse angiosperm seeds. All three species are distributed throughout the Southwest Botanical Province of Western Australia, albeit with $R$. inornata being more confined to the extreme south of this region. They are thus well situated to disperse seeds of many families found within this exceptionally biodiverse (Hopper and Gioia, 2004) region. It should be stressed that there are other species from both ant genera which are involved in myrmecochorous relationships, and members of other ant genera as well.

All three species exhibit a diurnal and seasonal activity that coincides with periods of seed production, which ranges from around $1-4$ months after the main September - October flowering period (Majer, 1980a), with seeds tending to fall during daytime, when hot conditions cause certain fruits to desiccate and shed seeds (B. Lamont, personal communication). Nevertheless, as flowering of myrmecochore and nonmyrmecochore plant species were closely correlated, it does not appear that phenologies have evolved to take advantage of, for instance, the increase activity level of ants in the spring-summer months. It therefore appears that ant activity levels fortuitously correlate with seed production (i.e., a lag of approximately 3 - 4 months after flowering). By contrast, Guitián and Garrido, (2006), working in Spain, have found that myrmecochores flower approximately 4 weeks before non-myrmecochores, possibly as an adaptation to produce seed at a time of maximal ant activity.

On the whole, Rhytidoponera activity is less seasonal and coincides less with seedfall than does Melophorus activity. Inspection of the food carrying data for $R$. violacea and $M$. turneri perthensis, and also the midden analysis of all three species, indicates that Melophorus appears to be more dependent on seeds than Rhytidoponera. This suggests that throughout the year, Rhytidoponera probably switches to other food sources, such as winter-active invertebrates. We suspect that Rhytidoponera does not store seeds for long periods of time, as evidenced by nest diggings reported in Majer (1982) and the fact that seeds taken to the nest are often returned to the surface in less than 12 hours (A. Gove, personal observation). Therefore Rhytidoponera is likely to be relying upon other food sources throughout much of the year, rather than storing seed for long periods. 
All three species have relatively shallow nests, although at least for Melophorus, nests tend to be deeper in the sandplain than in the lateritic soils. Colony sizes are relatively low and, in the case of Melophorus, are much lower than for the larger nests of Melophorus bagoti Lubbock from more arid parts of Australia (Conway, 1992). The dependence upon seeds, rather than carbohydrates in nectar form, may account for the small nests, unlike the situation with high nest abundance species that are dependent upon liquid carbohydrates (Davidson et al. (2004). Despite this, nest densities were relatively high, averaging 675 nests per ha for both $R$. inornata and $M$. turneri perthensis, and probably similarly high for $R$. violacea in areas where it is present. Combining the data on density of nests with the quantity of seeds found in forage and on middens indicates the high importance of these species in the dynamics of seed dispersal.

The structure of the nests also has a bearing on the survival of seeds and germination of the resulting seedlings. Many of the plant species dispersed by these ants are obligate seeders (Bell, 2001) which often rely on fire to germinate the seeds. Nest sievings reported in Majer (1982) indicate that seed tends to be buried in nests or under middens at a depth which is likely to be protected from the extreme effects of fire, but heated sufficiently for seed to germinate (Portlock et al., 1990). The nest heating experiment demonstrates this effect quite clearly. The preference of $M$. turneri perthensis for open conditions might have positive feedback effects on the plant community, with seedlings being encouraged to germinate in open areas where plants have died and opened up the canopy.

All three ant species have been found to survive fire, although, surprisingly for a thermophilic species (Hoffmann, 1998), Melophorus may be more impacted than Rhytidoponera. At this stage, we are unsure about the reason for this difference, although its greater dependence on seeds in its diet when compared with Rhytidoponera might leave it less equipped to switch to other food sources when fire depletes the supply of plants which produce seeds. Some of the colonies used for assessment of food collection were subject to a cool autumn burn during the course of the study (see Majer, 1984 for details), and foraging continued after the burn, with seed in the diet often being replaced with burnt plant fragments (J. Majer, unpublished data).

In our study of the importance of Rhytidoponera, seed removal rate was closely related to the presence of Rhytidoponera (Gove et al., 2007). However, in examining this data set further, seed removal rate was not associated with Melophorus presence $\left(\mathrm{F}_{1,16}=0.996, \mathrm{P}=0.335\right)$. Why, if in our retrospective study Melophorus was seen carrying far more seed than Rhytidoponera; didn't the Gove et al. study register a more significant role of Melophorus? Trials in Gove et al. began at approximately $0800 \mathrm{hrs}$ and, although they often continued during times when temperatures were in the high 30's, they were biased towards the cooler part of the day when Rhytidoponera was more active than Melophorus. Had the trials been focussed on the hotter part of the day, the undoubtledly important role of Melophorus would probably have become more clear.

The pivotal role that these ant species play in the dispersal, survival and therefore conservation of native plants, many of which are highly endemic and possibly threatened (Hopper and Gioia, 2004), highlights the need to understand and preserve this important plant-insect interaction. How well do these three species cope with habitat disturbance then? The extensive studies which J. Majer has undertaken in the southwest of Western Australia indicate that all three species can tolerate a high degree of habitat disturbance. 
Furthermore, when totally disturbed areas such as minesites are rehabilitated, all three species are early colonizers of the area (Majer and Nichols, 1998). Seed removal trials in the maturing vegetation indicate that the myrmecochorous relationship is also rapidly restored (Majer, 1980b). The situation is less optimistic when invasive ants are involved. Callan and Majer (2009) quantified the impact of progressively increasing densities of the invasive ant, Pheidole megacephala (Fabricius) intruding into Perth native woodland on the Swan Coastal Plain. The smaller $R$. inornata and, to a lesser extent, the larger $R$. violacea, were vulnerable to incursions of this ant, with the former being eliminated when Pheidole was present at the lowest density, and the latter disappearing when Pheidole densities reached 100 per pitfall trap. By contrast, close relatives of $M$. turneri perthensis were able to coexist with all but very high densities of the invasive ant $(>1000$ ants per pitfall trap), probably as a result of the ability to forage during high temperatures when the invasive species is inactive. The impact of these changes in composition of myrmecochorous ants was not investigated, but it is assumed that this will result in changes in the dynamics of the relationship.

To summarise, this paper confirms the important role that these three ants have in the dispersal and survival of seeds in the southwest of Western Australia. All three species have foraging and feeding strategies which maximise the collecting and dispersal of seeds and placing them in positions which are ideally suited for subsequent germination and survival. This aspect of the relationship is explored further in the case of $R$. violacea in a forthcoming paper (Lubertazzi et al., in press) and in an, as yet unpublished, MSc thesis (McCoy, 2008).

\section{Acknowledgements}

This work was funded by a grant from the discontinued, Reserve Bank Rural Credits Development Fund. Chris Portlock's contribution was funded by his previous employer, the now defunct Forests Department of Western Australia. Prof Andy Beattie, Dr Rob Dunn, Dr Brian Heterick, Dr Ben Hoffmann and Dr David Lubertazzi are thanked for their comments on an earlier draft of this manuscript.

\section{References}

Andersen A. N. 2007. Ant diversity in arid Australia: a systematic overview. In: Advances in Ant Systematics (Hymenoptera: Formicidae): Homage to E. O. Wilson - 50 Years of Contributions. (Snelling R. R., Fisher B. L and Ward P. S., eds). Memoirs of the American Entomological Institute, 80, pp. 19-51.

Bell D. T. 2001. Ecological response syndromes in the flora of southwestern Australia: fire resprouters versus reseeders. Botanical Review 67:4 17-40.

Briese D. T. and Macauley B. J. 1981. Physical structure of an ant community in semiarid Australia. Australian Journal of Botany 2: 107-120.

Callan S. K. And Majer J. D. 2009. Impacts of an incursion of African Big-headed ants, Pheidole megacpephala (Fabricius), in urban bushland in Perth, Western Australia. Pacific Conservation Biology 15: 102-115. 
Christian K. A. and Morton S. R. 1992. Extreme thermophilia in a central Australian ant, Melophorus bagoti. Physiological Zoology 65: 885-905.

Conway J. R. 1992. Notes on the excavation of a nest of Melophorus bagoti Lubbock in the Northern Territory, Australia (Hymenoptera: Formicidae). Journal of the Australian Entomological Society 31: 247248.

Davidson, D. W., Cook, S. C. and Snelling, R. R. 2004. Liquid-feeding performances of ants (Formicidae): ecological and evolutionary implications. Oecologia 139: 255-266.

Dunn R., Gove A. and Majer J. D. 2008. Seed dispersal mutualisms with ants and patterns of plant diversity in western Australia. In: Fronteiras do Conhecimento em Insetos Socais. (Vilela E. F., Santos I. A., Schoereder J. H., Campos L. A. O. and Serrão J. E., eds.). Editora Universidade Federal de Viçosa, MG. pp. 325-347.

Estabrook G. F., Winsor J. A., Stephenson A. G. and Howe H. F. 1982. When are two phenological patterns different? Botanical Gazette 143: 374-378.

Gove A. D., Dunn R. R. and Majer J. D. 2007. A keystone ant species promotes seed dispersal in a "diffuse" mutualism. Oecologia 153: 687-657.

Guitián J. and Garrido J. L. 2006. Is early flowering in myrmecochorous plants an adaptation for ant dispersal? Plant Species Biology 21: 165-171.

Hoffmann B. D. 1998. Thermophilia in a tropical Australian ant of the Melophorus aenovirens (Lowne) species-group (Hymenoptera: Formicidae) Australian Journal of Entomology 37: 162-167.

Hopper S. D. and Gioia P. 2004. The southwest Australian floristic region: evolution and conservation of a global hot spot of biodiversity. Annual Review of Ecology, Evolution, and Systematics 35: 623-650

Koch L. E. and Majer J. D. 1980. A phenological investigation of various invertebrates in forest and woodland areas in the south-west of Western Australia. Journal of the Royal Society of Western Australia 63: 21-28.

Lengyel S., Gove A. D., Latimer A. M., Majer, J., D. and Dunn R. R 2009a. Ants sow the seeds of global diversification in flowering plants. PLOS ONE 4(5): e5480.

Lengyel S., Gove A. D., Latimer A. M., Majer, J., D. and Dunn R. R 2009b. Convergent evolution of seed dispersal by ants, and phylogeny and biogeography in flowering plants: A global survey. Perspectives in Plant Ecology, Evolution and Systematics 12: 43-55.

Lubertazzi. D., Aliberti-Lubertazzi M., McCoy N., Gove A. D., Majer J. D. and Dunn R. $\mathrm{R}$. in press. The ecology of a keystone seed disperser, Rhytidoponera violacea, with implications for the evolution of myrmecochory.Journal of Insect Science $\mathbf{X}$ : xx-xx. 
Majer J. D. 1980a. A flowering calendar for Karragullen, a northern Jarrah forest locality. W. A. Herbarium Research Notes No. 5: 19-28.

Majer J. D. 1980b. The influence of ants on broadcast and naturally spread seeds in rehabilitated bauxite mines. Reclamation Review 3: 3-9.

Majer J. D. 1982. Ant-plant interactions in the Darling Botanical District of Western Australia. In: Ant-Plant Interactions in Australia. (Buckley R. ed.) Dr W. Junk, Dordrecht. pp. 45-61.

Majer J. D. 1984. Short-term responses of soil and litter invertebrates to a cool autumn burn in jarrah (Eucalyptus marginata) forest in Western Australia. Pedobiologia 26: 229-247.

Majer J. D. and Nichols O. G. 1998. Long-term recolonization patterns of ants in Western Australian rehabilitated bauxite mines with reference to their use as indicators of restoration success. Journal of Applied Ecology 35: 161-182.

McCoy N. 2008. The geographic mosaic of myrmecochory in a global biodiversity hotspot and the fate of seeds dispersed by a keystone seed disperser. MSc thesis, North Carolina State University.

Myers N., Mittermeier R. A., Mittermeier C. G.; da Fonseca G. A. B. and Kent, J. 2000.

Biodiversity hotspots for conservation priorities. Nature. 403(6772):853-858.

Nielsen M. G. 1997. Foraging strategy and energetic cost of food transport in the ant Rhytidoponera aurata (Roger) in tropical Australia. Procedings of the International Colloquia on Social Insects (Kipyatkov V. E., ed.). IUSSI, St Petersberg, vol 3, pp. 247252.

Portlock C. C., Shea S. R., Majer J. D. and Bell D. T. 1990. Stimulation of germination of Acacia pulchella: laboratory basis for forest management options. Journal of Applied Ecology 27: 319-324.

Ward P. S. 1981. Ecology and life history of the Rhytidoponera impressa group (Hymenoptera: Formicidae). 1. Habitats, nest sites and foraging behavior. Psyche 88: 89108. 
Table 1 Summary of site and sampling or observation details

\begin{tabular}{|c|c|c|c|c|c|c|c|c|}
\hline Site & & Latitude & Longitude & Sample period & $\begin{array}{l}\text { Burn \& } \\
\text { control? }\end{array}$ & Rhytidoponera spp. & Melophorus sp. & Burn date \\
\hline Perth & $\begin{array}{l}\text { Reabold } \\
\text { Hill }\end{array}$ & $31^{\circ} 56^{\prime} 21^{\prime \prime}$ & $115^{\circ} 46^{\prime} 34^{\prime \prime}$ & $\begin{array}{l}\text { March } 1976- \\
\text { Feb } 1978\end{array}$ & No & R. inornata, R. violacea & M. turneri perthensis & -- \\
\hline Yalgorup & & $32^{\circ} 50^{\prime} 7^{\prime \prime}$ & $115^{\circ} 40^{\prime} 8^{\prime \prime}$ & $\begin{array}{l}\text { Various } \\
\text { observations }\end{array}$ & No & -- & -- & -- \\
\hline Karragullen & & $32^{\circ} 7^{\prime} 8^{\prime \prime}$ & $116^{\circ} 7^{\prime} 14^{\prime \prime}$ & $\begin{array}{l}\text { Feb } 1978 \text { - April } \\
1979\end{array}$ & Yes & $R$. inornata, $R$. violacea & M. turneri perthensis & 29-Mar-78 \\
\hline Dwellingup & Plavins & $32^{\circ} 45^{\prime} 0^{\prime \prime}$ & $116^{\circ} 9^{\prime} 0^{\prime \prime}$ & $\begin{array}{l}\text { March } 1975 \text { - } \\
\text { April } 1976\end{array}$ & Yes & R. inornata & M. turneri perthensis & 11-Apr-75 \\
\hline Dwellingup & Curara & $28^{\circ} 35^{\prime} 0^{\prime \prime}$ & $115^{\circ} 34^{\prime} 0^{\prime \prime}$ & $\begin{array}{l}\text { Feb } 1976 \text { - April } \\
1977\end{array}$ & Yes & $\begin{array}{l}R \text {. inornata, } R \text {. violacea } \\
\text { (burnt plot only) }\end{array}$ & M. turneri perthensis & 10-Apr-76 \\
\hline Dwellingup & Pindalup & $32^{\circ} 47^{\prime} 0^{\prime \prime}$ & $116^{\circ} 15^{\prime} 0^{\prime \prime}$ & $\begin{array}{l}\text { Feb } 1976-\text { Jan } \\
1978\end{array}$ & Yes & $R$. inornata, $R$. violacea & M. turneri perthensis & 25-Nov-76 \\
\hline Manjimup & & $34^{\circ} 20^{\prime} 0^{\prime \prime}$ & $116^{\circ} 0^{\prime} 0^{\prime \prime}$ & $\begin{array}{l}\text { March } 1976 \text { - } \\
\text { Feb } 1978\end{array}$ & No & R. inornata & -- & \\
\hline
\end{tabular}


Table 2 Depth of nests of $R$. inornata, $R$. violacea and $M$. turneri perthensis on laterite soils at Dwellingup and of $M$. turneri perthensis on sandy soils at Yalgorup National Park

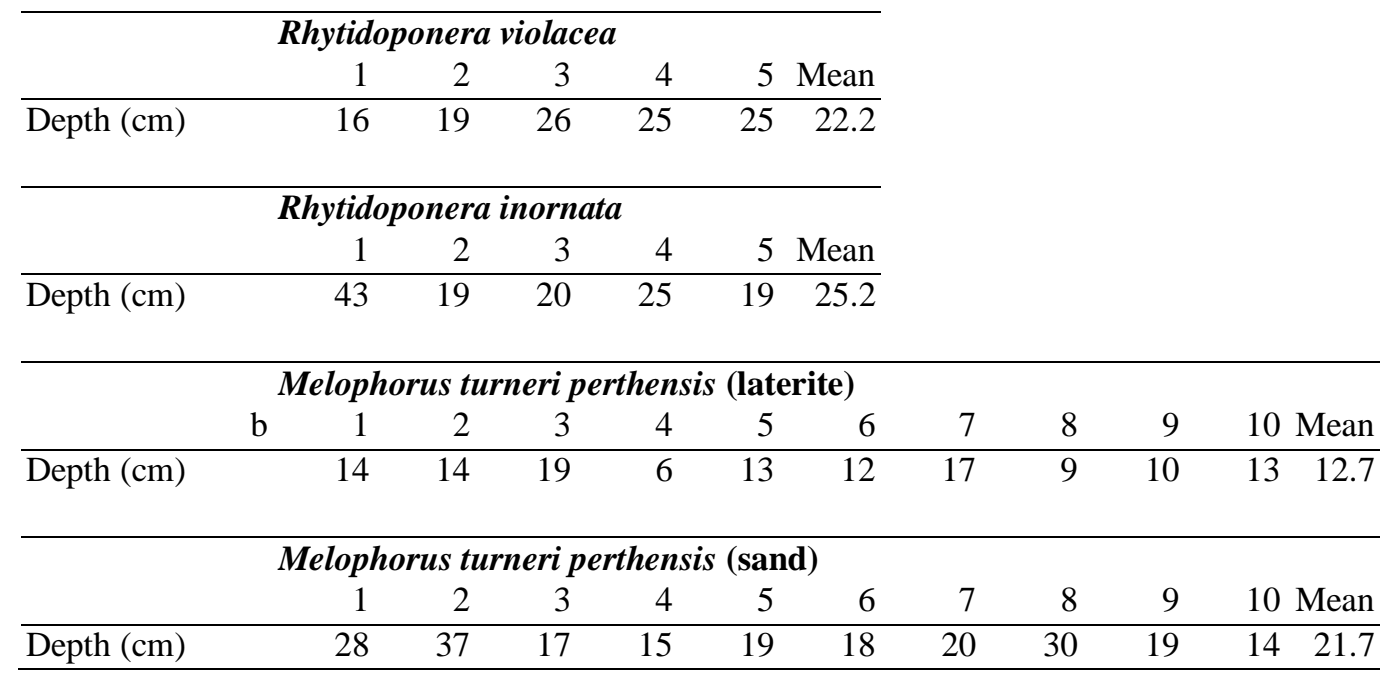


Table 3 Numbers of worker and alate ants in five $R$. violacea and five $R$. inornata nests measured at Karragullen and five $M$. turneri perthensis nests measured at Perth. All nest were collected during the peak summer foraging period.

\begin{tabular}{|c|c|c|c|c|c|c|c|c|c|c|c|c|c|c|c|c|c|c|}
\hline & \multicolumn{6}{|c|}{ Rhytidoponera violacea } & \multicolumn{6}{|c|}{ Rhytidoponera inornata } & \multicolumn{6}{|c|}{ Melophorus turneri perthensis } \\
\hline & 1 & 2 & 3 & 4 & 5 & Mean & 1 & 2 & 3 & 4 & 5 & Mean & 1 & 2 & 3 & 4 & 5 & Mean \\
\hline Workers & 46 & 359 & 176 & 150 & 135 & 173.2 & 37 & 194 & 403 & 290 & 64 & 197.6 & 257 & 241 & 256 & 247 & 151 & 230.4 \\
\hline Alate males & 8 & 0 & 101 & 295 & 75 & 95.8 & 147 & 1 & 27 & 6 & 46 & 45.4 & 0 & 0 & 0 & 0 & 0 & 0 \\
\hline Alate females & 0 & 0 & 0 & 0 & 0 & 0 & 0 & 57 & 0 & 91 & 0 & 29.6 & 0 & 0 & 0 & 0 & 0 & 0 \\
\hline
\end{tabular}


Table 4 Quantities of food items carried to $R$. violacea $(\mathrm{n}=5)$ and $M$. turneri perthensis $(\mathrm{n}=10)$ nests at Karragullen. Measurements made in most months between March 1978 and April 1979 for 30-minute periods per nest

\begin{tabular}{|c|c|c|c|c|c|c|c|c|c|c|c|c|c|}
\hline & & Mar & May & Jun & Jul & Aug & Sep & Oct & Nov & Dec & Mar & Apr & $\%$ \\
\hline \multirow[t]{3}{*}{ R. violacea } & Seeds & 3 & 2 & 0 & 0 & 0 & 0 & 0 & 0 & 0 & 0 & 0 & 6.3 \\
\hline & Plant fragments & 1 & 0 & 0 & 0 & 1 & 0 & 0 & 0 & 0 & 0 & 0 & 2.5 \\
\hline & Invertebrates & 7 & 13 & 3 & 7 & 6 & 6 & 6 & 6 & 3 & 8 & 8 & 91.2 \\
\hline \multirow[t]{3}{*}{ M. turneri perthensis } & Seeds & 4 & $*$ n.f. & n.f. & n.f. & n.f. & n.f. & n.f. & 3 & 9 & 2 & 5 & 29.1 \\
\hline & Plant fragments & 2 & n.f. & n.f. & n.f. & n.f. & n.f. & n.f. & 8 & 2 & 3 & 5 & 25.3 \\
\hline & Invertebrates & 11 & n.f. & n.f. & n.f. & n.f. & n.f. & n.f. & 4 & 5 & 8 & 8 & 45.6 \\
\hline
\end{tabular}

*n.f. indicates not foraging 
Table 5 Analysis of nest middens of $R$. inornata $R$. violacea and $M$. turneri perthensis collected at Karragullen

\begin{tabular}{|c|c|c|c|c|c|c|c|c|c|c|c|c|c|c|c|c|c|c|c|c|c|}
\hline & \multicolumn{4}{|c|}{ Rhytidponera inornata } & \multicolumn{6}{|c|}{ Rhytidoponera violacea } & \multicolumn{11}{|c|}{ Melophorus turneri perthensis } \\
\hline & 1 & 2 & 3 & Mean & 1 & 2 & 3 & 4 & 5 & Mean & 1 & 2 & 3 & 4 & 5 & 6 & 7 & 8 & 9 & 10 & Mean \\
\hline Arthropods & 268 & 636 & 541 & 481.7 & 72 & 241 & 24 & 78 & 461 & 175.2 & 15 & 1 & 4 & 67 & 10 & 33 & 5 & 1 & 28 & 0 & 18.2 \\
\hline \multicolumn{22}{|l|}{ Seeds } \\
\hline Acacia pulchella & 0 & 0 & 0 & 0 & 0 & 2 & 0 & 0 & 0 & 0.4 & 0 & 0 & 0 & 0 & 0 & 0 & 0 & 0 & 0 & 0 & 0 \\
\hline Acacia sp. indet. & 1 & 2 & 3 & 2 & 1 & 1 & 27 & 0 & 0 & 5.8 & 0 & 0 & 0 & 0 & 0 & 0 & 0 & 0 & 0 & 0 & 0 \\
\hline Acacia browniana & 0 & 0 & 0 & 0 & 0 & 0 & 0 & 0 & 0 & 0 & 0 & 0 & 0 & 0 & 1 & 0 & 0 & 0 & 1 & 0 & 0.2 \\
\hline Allocasuarina sp.indet. & 1 & 2 & 0 & 1 & 0 & 0 & 1 & 3 & 0 & 0.8 & 0 & 0 & 0 & 0 & 0 & 0 & 0 & 0 & 0 & 0 & 0 \\
\hline Corymbia calophylla & 0 & 0 & 0 & 0 & 3 & 0 & 0 & 18 & 0 & 4.2 & 0 & 0 & 0 & 0 & 0 & 0 & 0 & 0 & 0 & 0 & 0 \\
\hline Eucalyptus marginata & 9 & 59 & 12 & 26.7 & 263 & 3 & 5 & 78 & 27 & 75.2 & 0 & 0 & 1 & 6 & 4 & 0 & 0 & 0 & 2 & 0 & 1.4 \\
\hline Hibbertia sp. & 0 & 1 & 0 & 0.3 & 0 & 0 & 0 & 0 & 0 & 0 & 0 & 0 & 0 & 0 & 0 & 0 & 0 & 0 & 0 & 0 & 0 \\
\hline Gompholobium tomentosum & 0 & 0 & 0 & 0 & 1 & 3 & 2 & 0 & 0 & 1.2 & 0 & 0 & 0 & 0 & 0 & 0 & 0 & 0 & 0 & 0 & 0 \\
\hline Phyllanthus calycinus & 0 & 0 & 0 & 0 & 0 & 0 & 0 & 0 & 0 & 0 & 0 & 0 & 0 & 0 & 0 & 1 & 0 & 0 & 3 & 0 & 0.4 \\
\hline Trymalium ledifolium & 0 & 0 & 0 & 0 & 0 & 0 & 0 & 0 & 0 & 0 & 60 & 0 & 0 & 0 & 0 & 2 & 0 & 0 & 0 & 0 & 6.9 \\
\hline Miscellaneous species & 6 & 7 & 21 & 11.3 & 4 & 37 & 42 & 7 & 0 & 18 & 13 & 0 & 0 & 6 & 5 & 33 & 13 & 5 & 3 & 0 & 8.7 \\
\hline Total seeds & 17 & 71 & 36 & 41.3 & 272 & 46 & 77 & 106 & 27 & 105.6 & 73 & 0 & 1 & 12 & 10 & 36 & 13 & 5 & 9 & 0 & 17.7 \\
\hline$\%$ Seeds & & & & 8.0 & & & & & & 37.6 & & & & & & & & & & & 49.3 \\
\hline
\end{tabular}


Fig. 1 Map of southwest Western Australia, showing sites where detailed observations or samples were taken for $R$. violacea, $R$. inornata and $M$. turneri perthensis. The solid black line shows the position of the Darling Scarp, which separates sandy soil to the west, from lateritic soil to the east

Fig. 2 Distribution maps of (a) $R$. violacea (b) R. inornata and (c) M. turneri perthensis (data provided from Biolink, CSIRO)

Fig. 3 Seasonal variation in activity of (a) R. violacea (b) R. inornata and (c) M. turneri perthensis at six sites. Error bars represent 1 standard error; vertical axes scales differ in the three graphs

Fig. 4 Diurnal activity of (a) R. violacea (b) R. inornata and (c) M. turneri perthensis over three seasons. Activity was quantified as the number of individuals leaving a nest over a three minute period, recorded each hour; vertical axes scales differ in the three

graphs; key: (•) summer, ( $\mathbf{\Delta})$ winter, $(\diamond)$ spring

Fig. 5 Effects of burning on activity of (a) R. violacea (b) R. inornata and (c) M. turneri perthensis in four sites. Key: ( $\square$ ) control plots.(o) burnt plots. Error bars represent 1 standard error; vertical axes scales differ in the three graphs

Fig. 6 Nest densities of $R$. inornata in terms of (a) ground cover and (b) overstorey shade and $M$. turneri perthensis in terms of (c) ground cover and (d) overstorey shade. Vertical axes scales differ in the three graphs

Fig. 7 Nest castings of (a) $R$. violacea, (b) $R$. inornata and (c) M. turneri perthensis. The two Rhytidoponera spp. were from laterite soil, and the nest of $M$. turneri perthensis was from sandy soil

Fig. 8 Relationships between activity of (a) R. violacea, (b) R. inornata and (c) M. turneri perthensis and the species density of flowering myrmecochores at Karragullen, WA. Vertical axes scales differ in the three graphs

Fig. 9 Photos of seedling emergence from heated nests of $R$. inornata. The inner rectangles show the heated area and the outer rectangles delimit areas affected by lateral conduction of heat

Fig. 10 Seedling emergence from nests and also heated and unheated un-nested soil $1 \mathrm{~m}$ away from nests for (a) R. inornata and (b) M. turneri perthensis. Vertical axes scales differ in the two graphs; square symbols are Acacia pulchella, circles are Trymalium ledifolium. 
Fig. 1

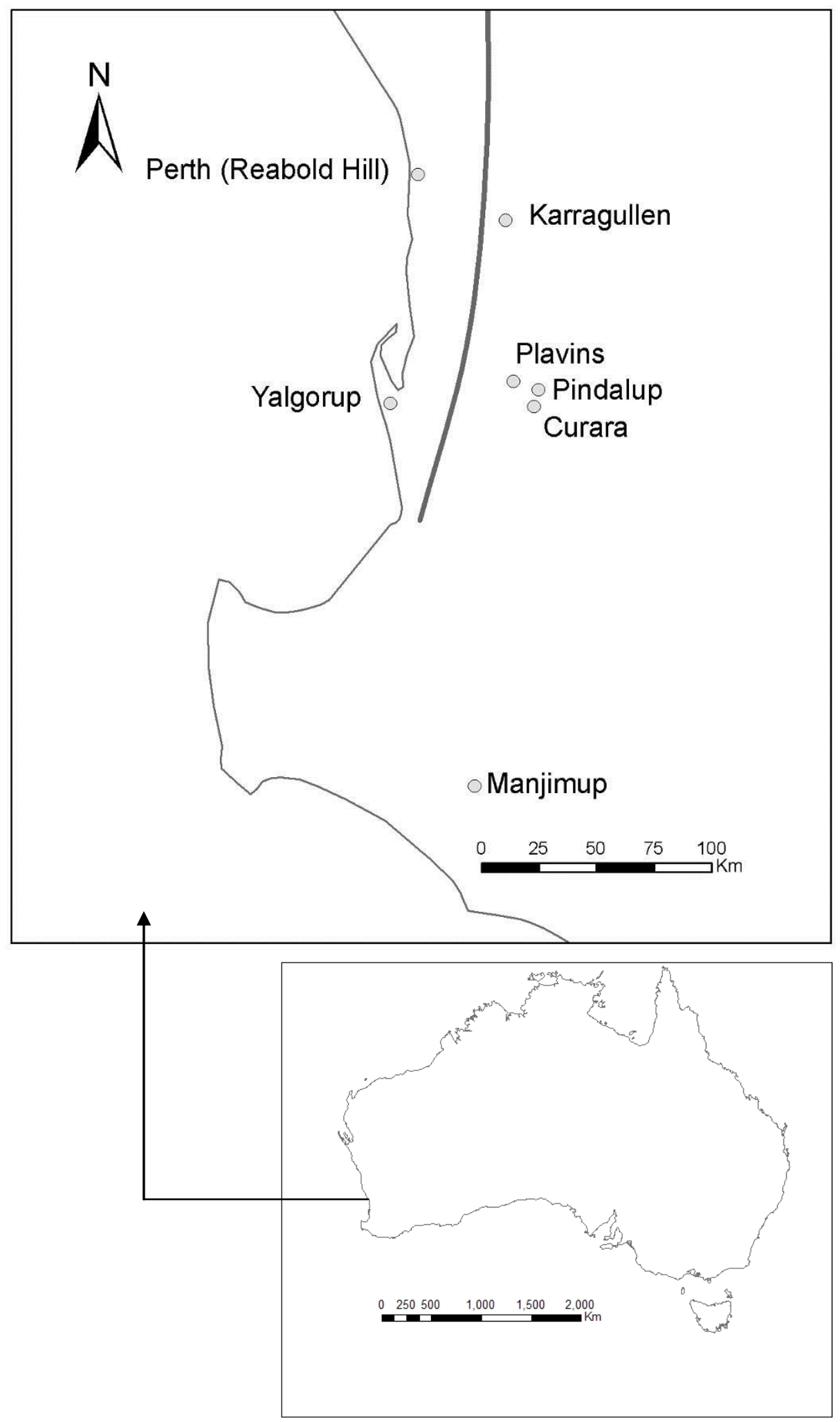


Fig 1.
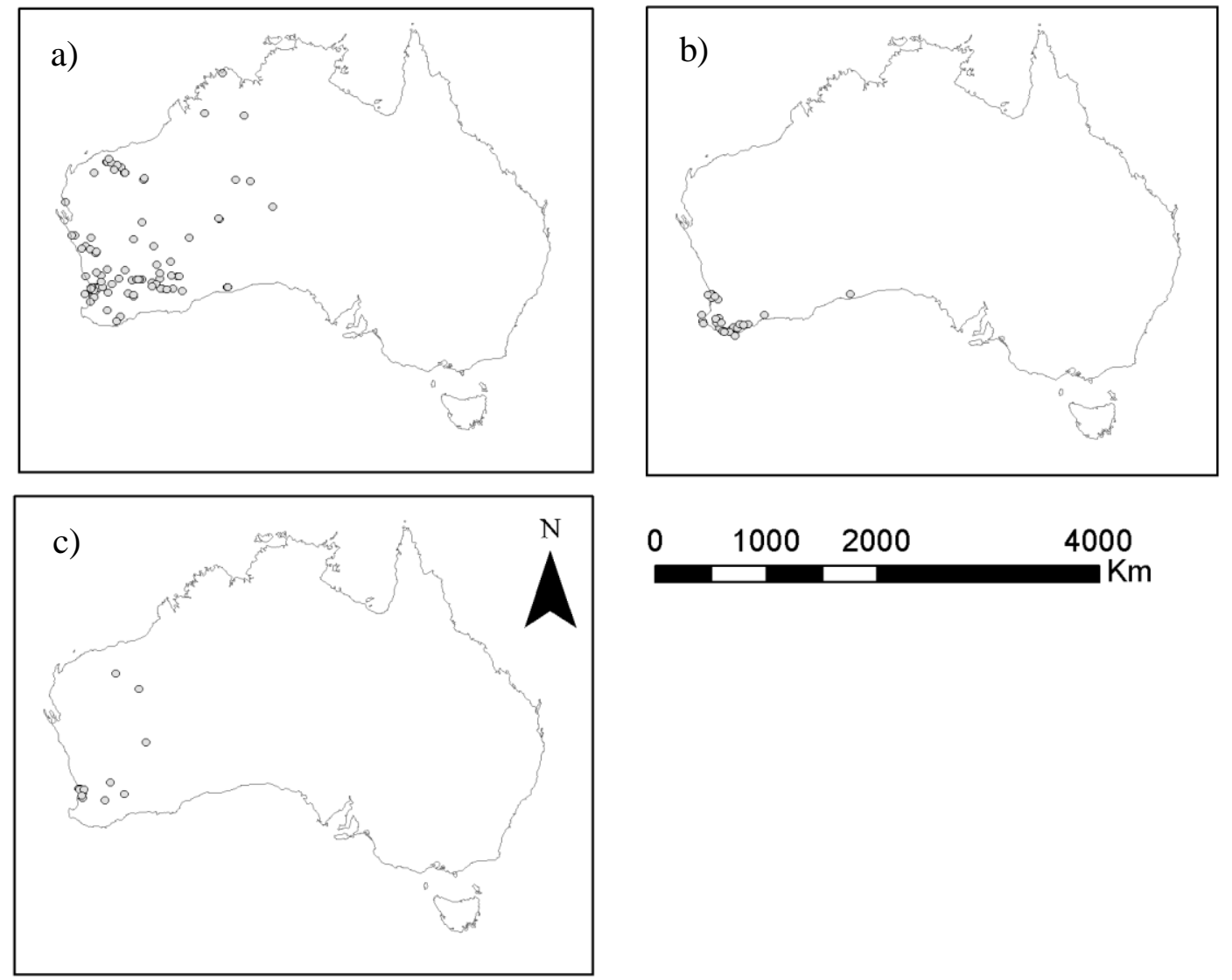
Fig. 3

(a)

(b)
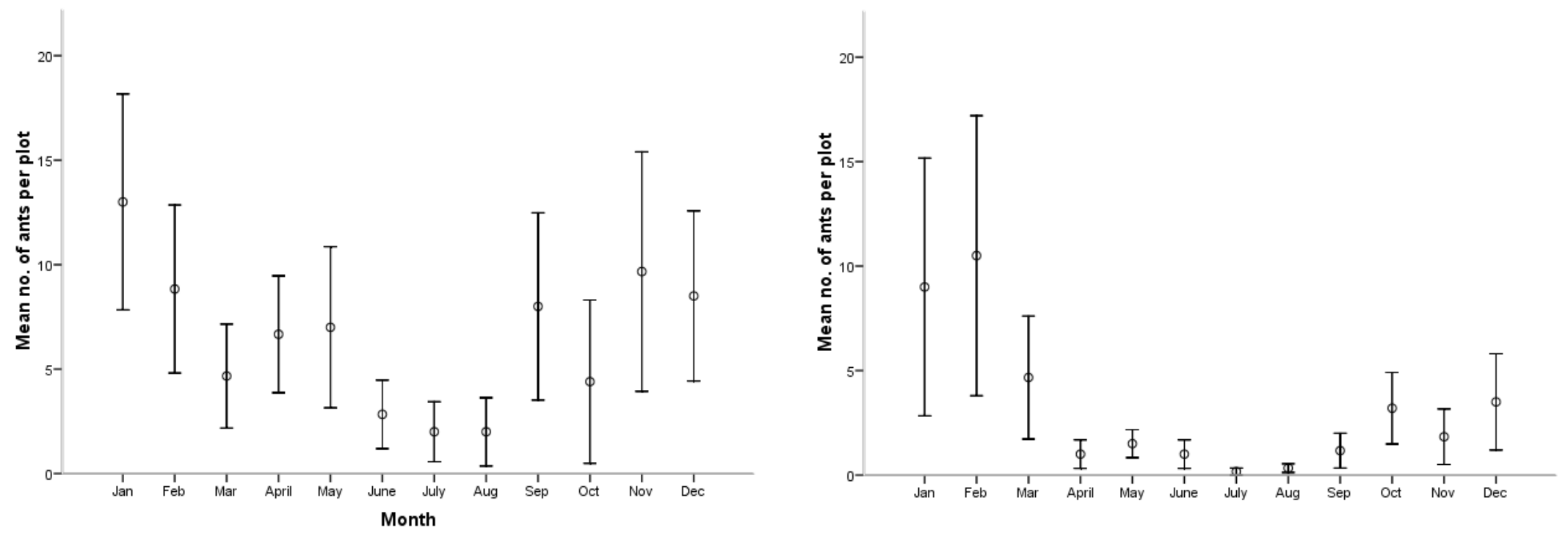

(c)

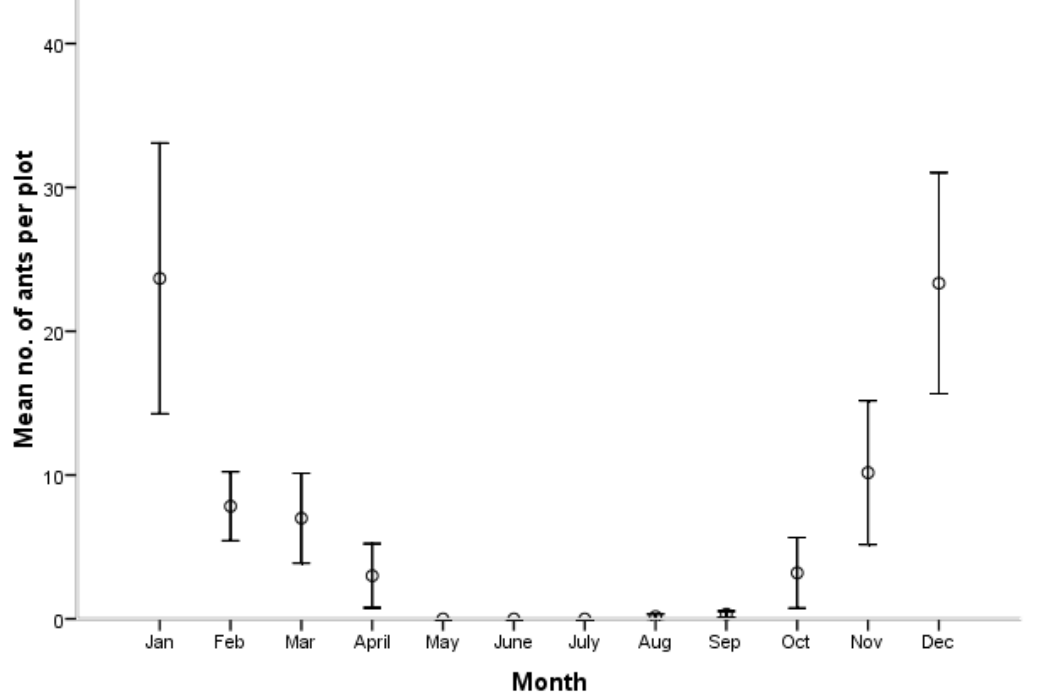


Fig 4

(a)

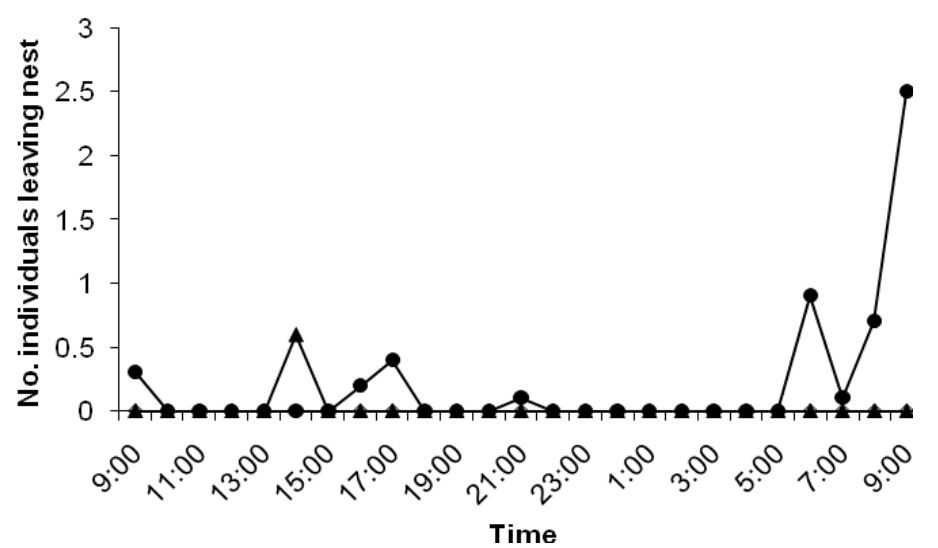

(b)

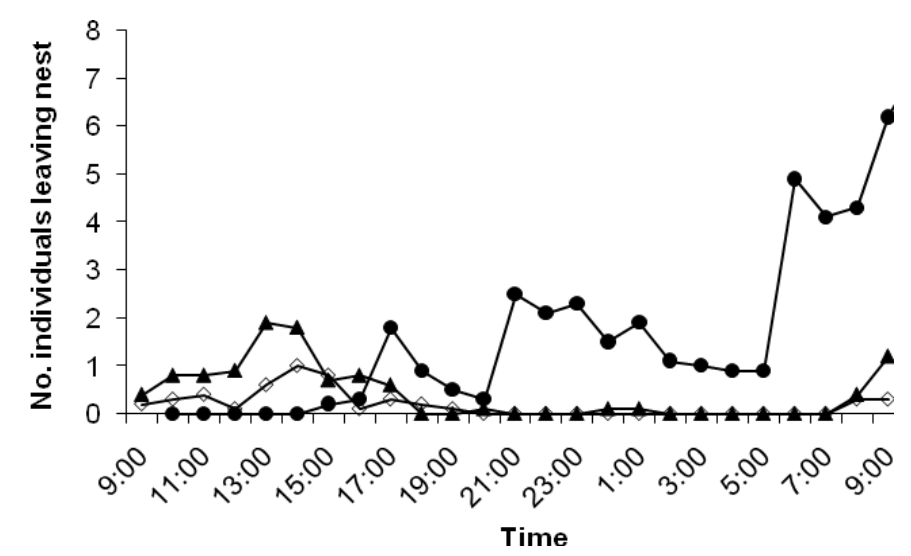

(c)

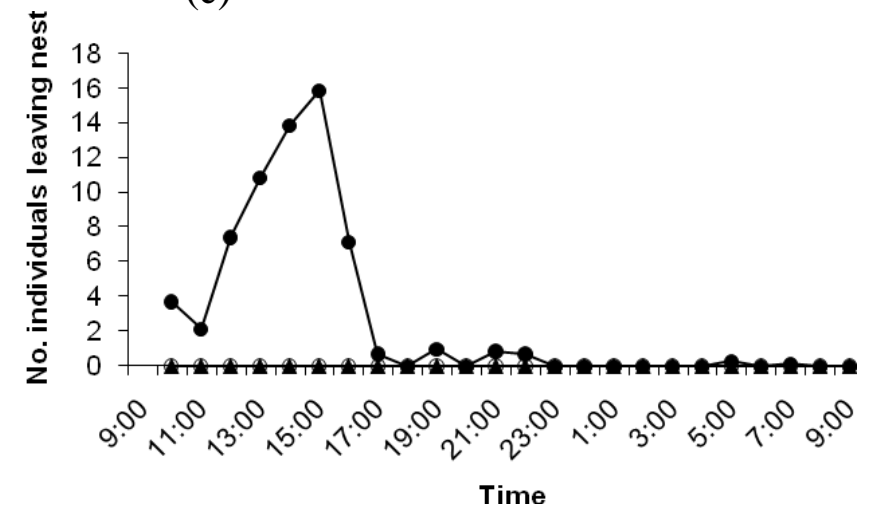


Fig. 5

(a)

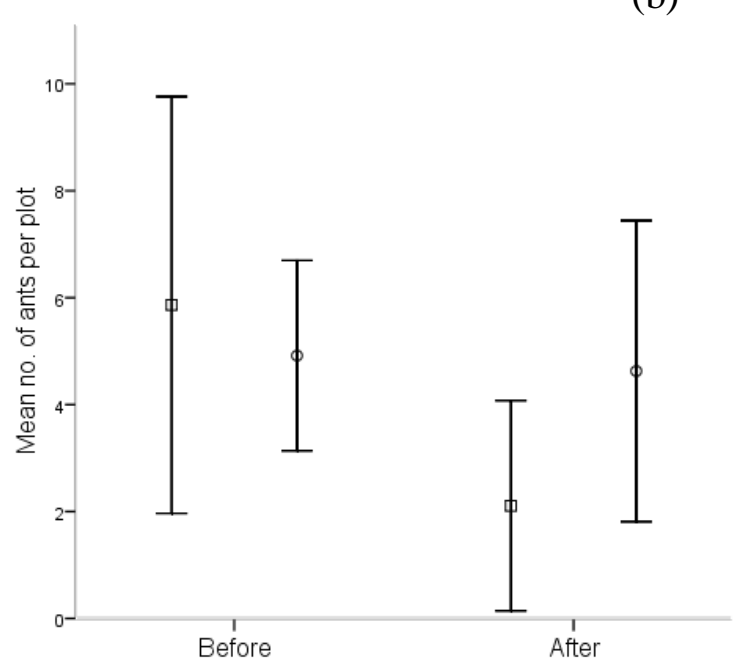

(c)

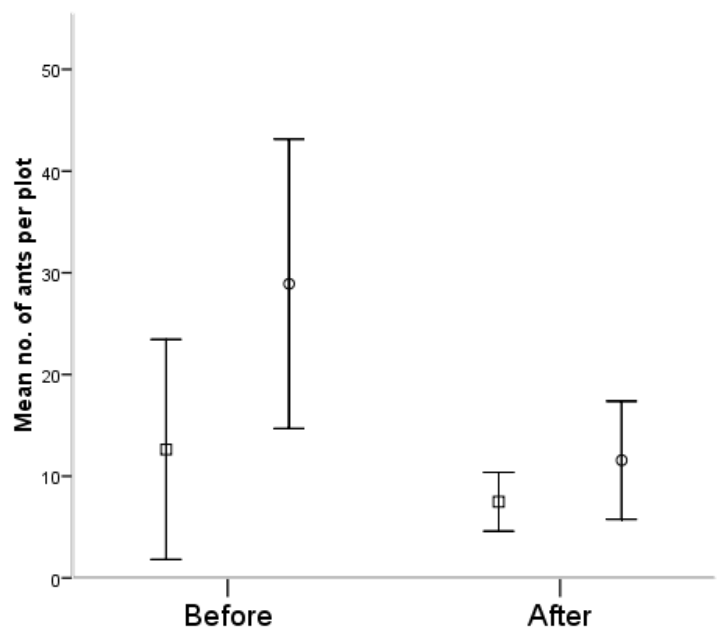

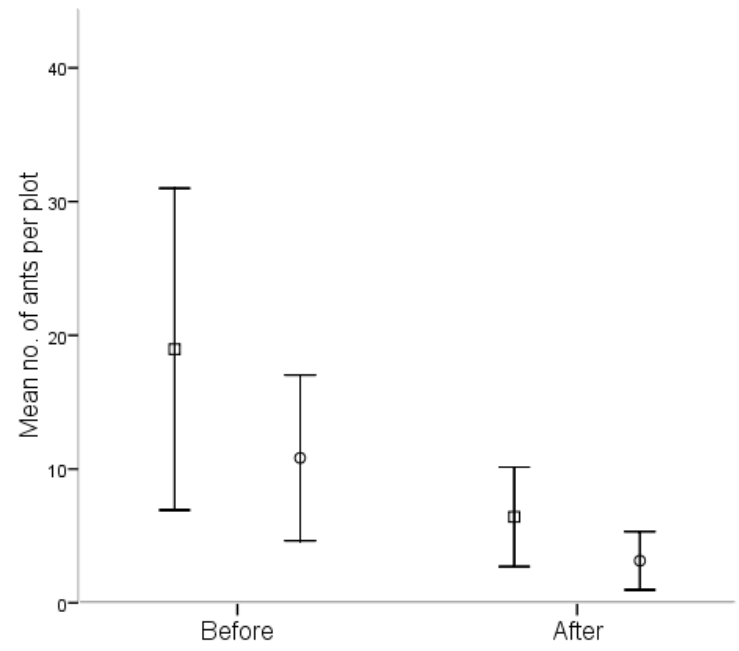


Fig. 6

(a)

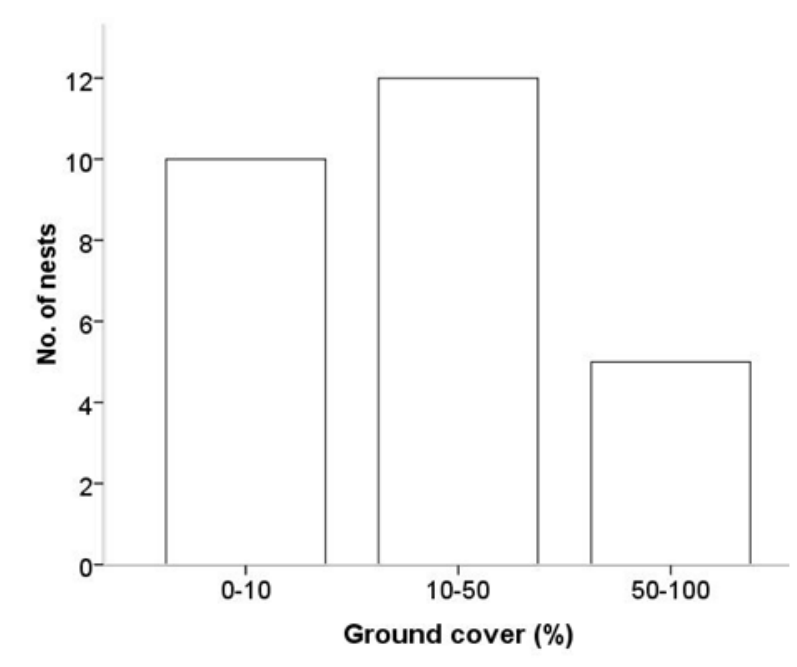

(b)

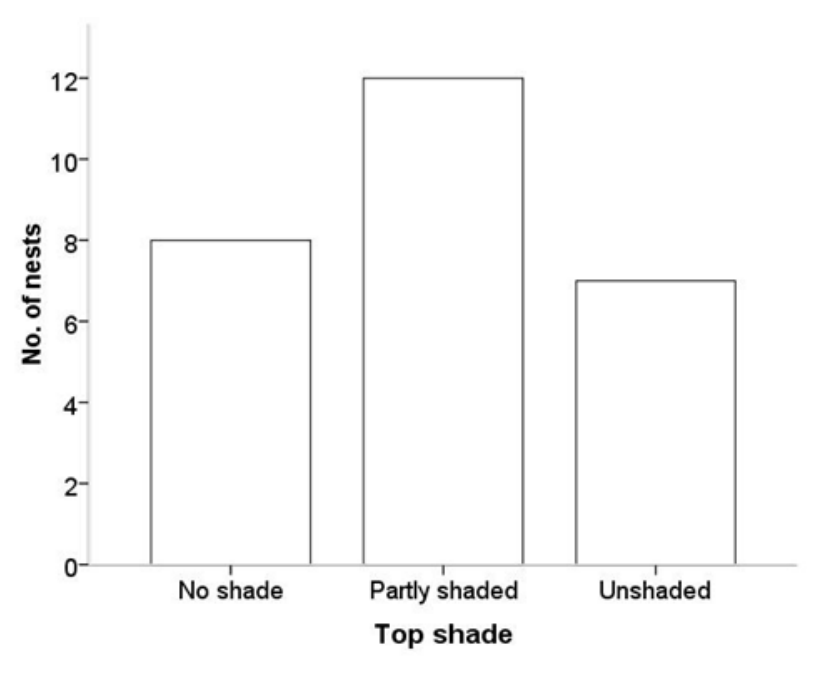

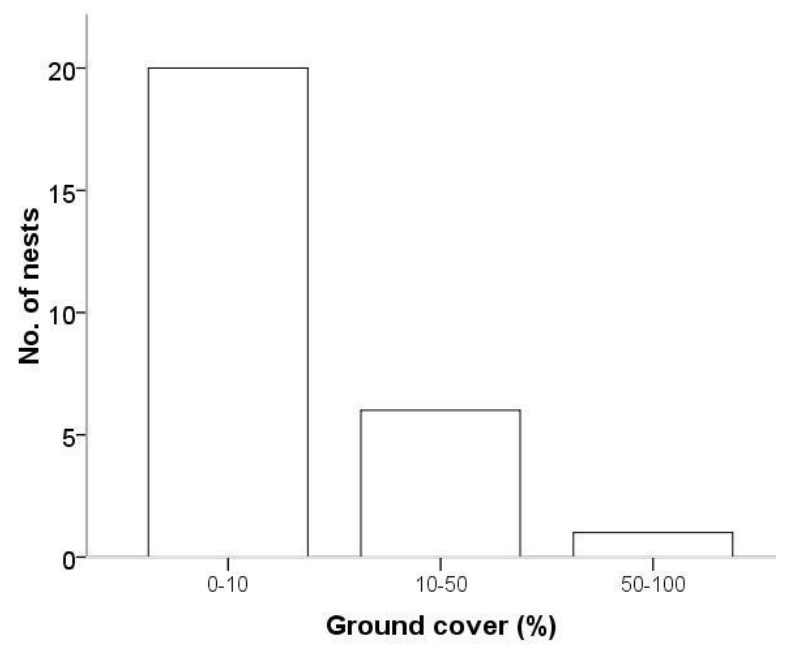

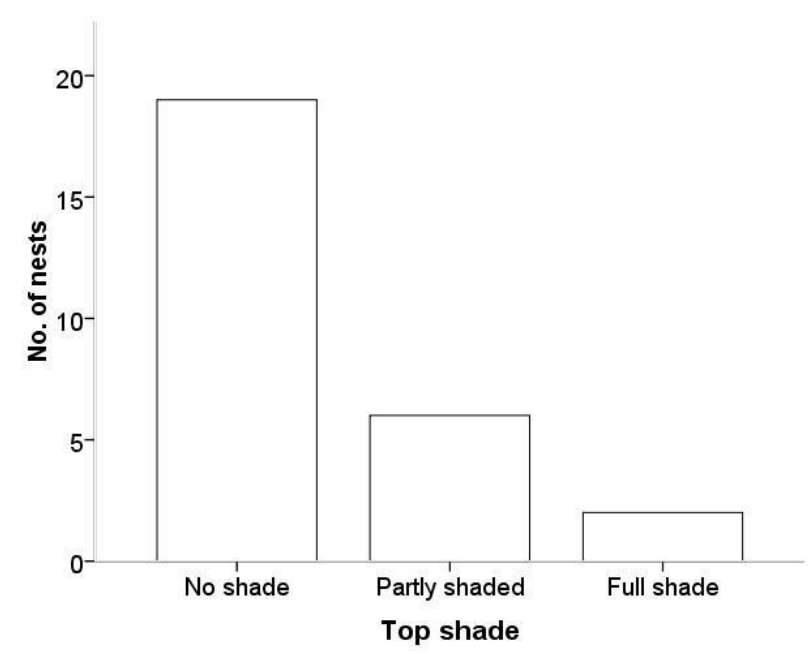


Fig.7

(a)

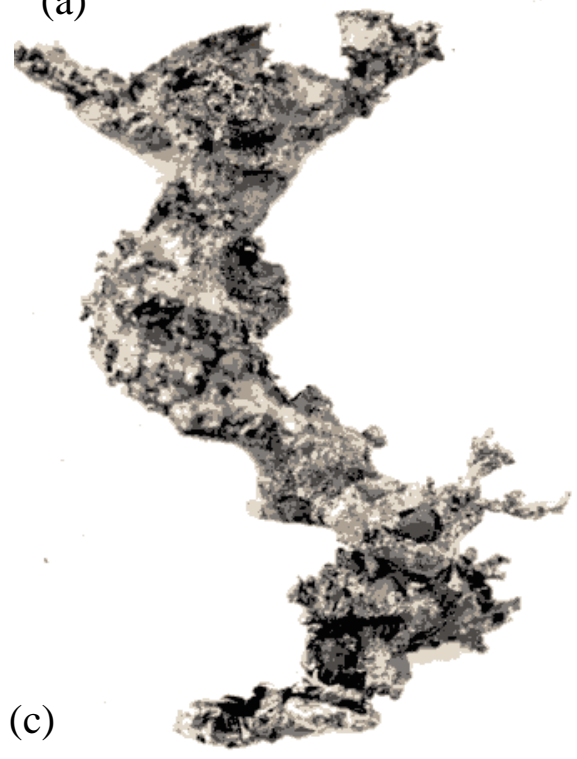

(b)

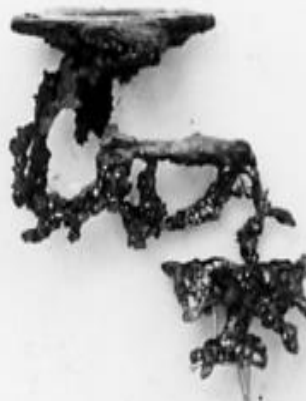

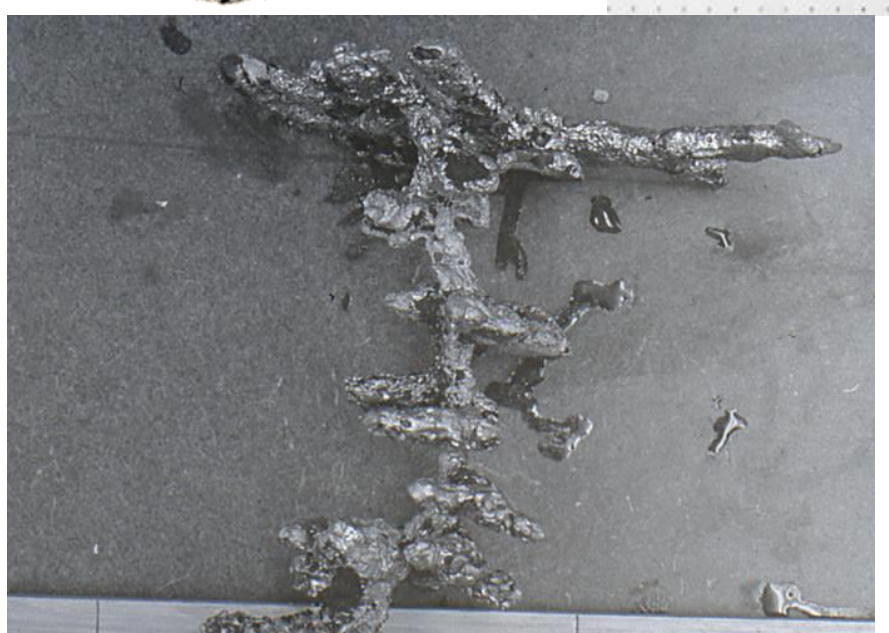

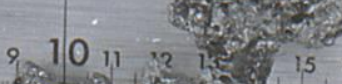

$\begin{array}{llllllllllll}15 & 16 & 17 & 18 & 19 & 2 & 0_{2} & 21 & 22 & 23 & 24 & 25\end{array}$

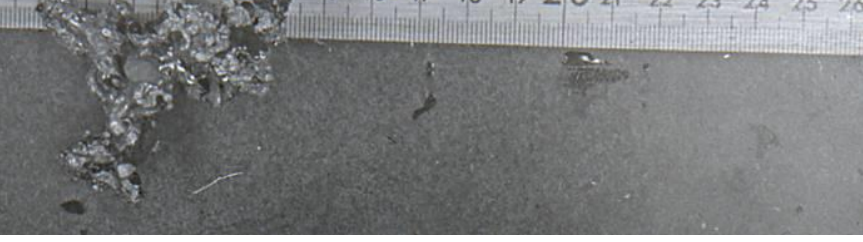


Fig.8.
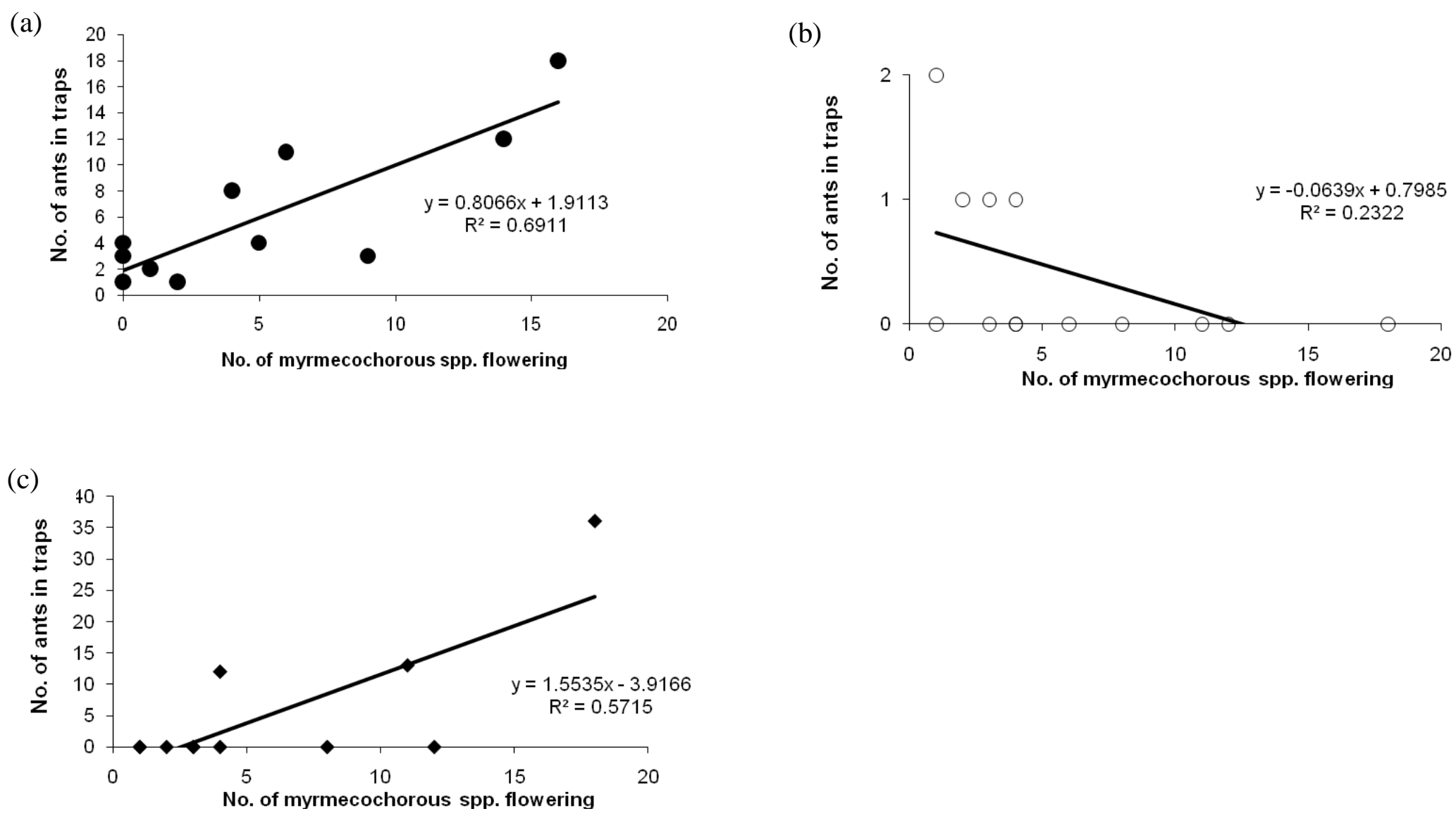
Figure 9

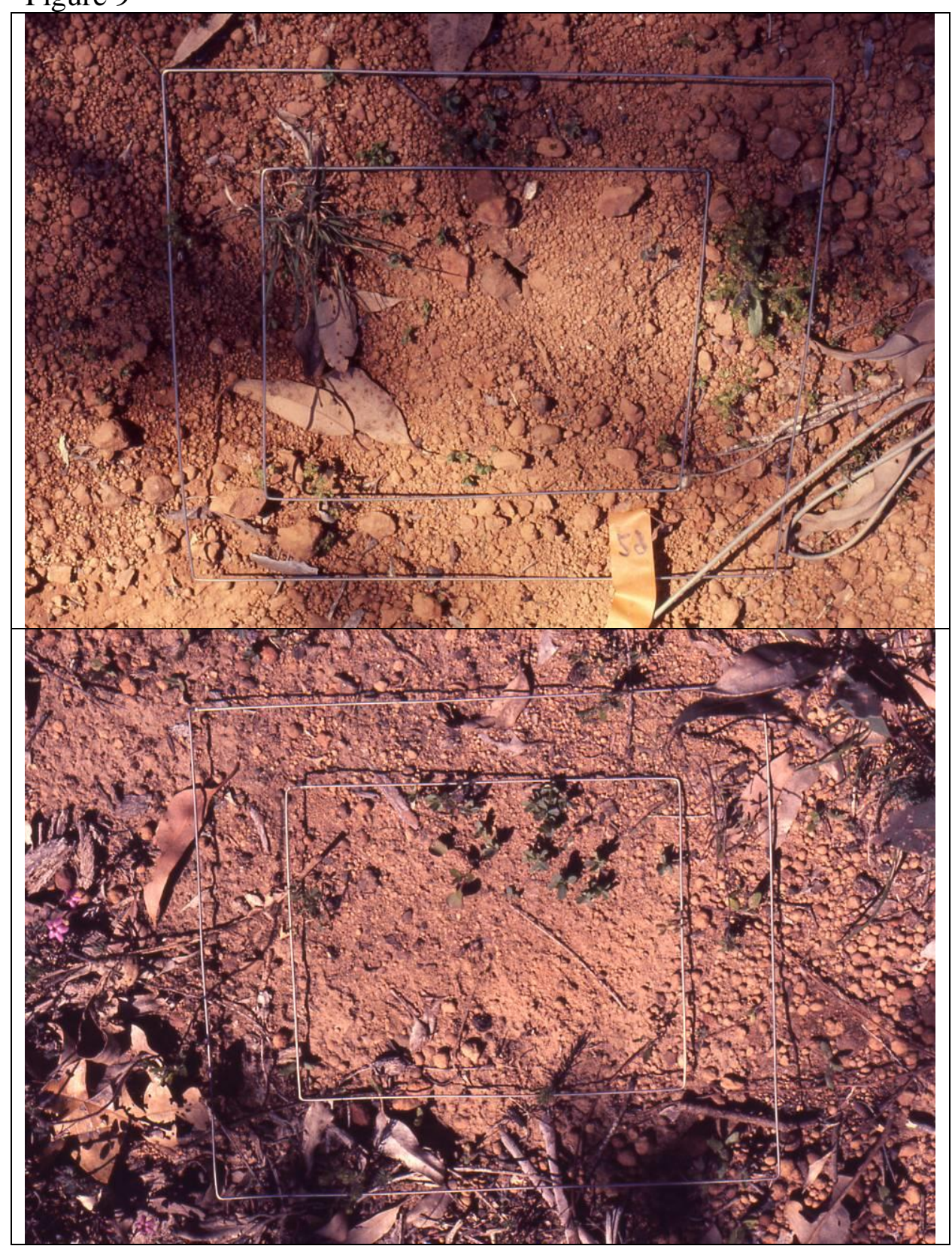


Fig 10

(a)

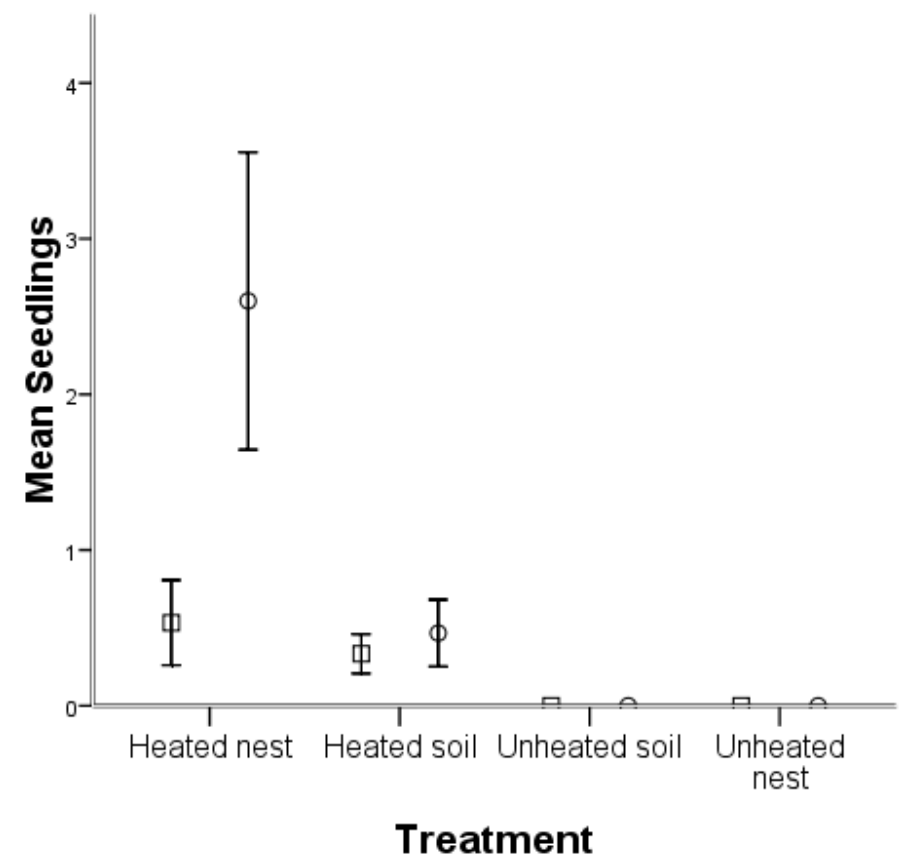

(b)

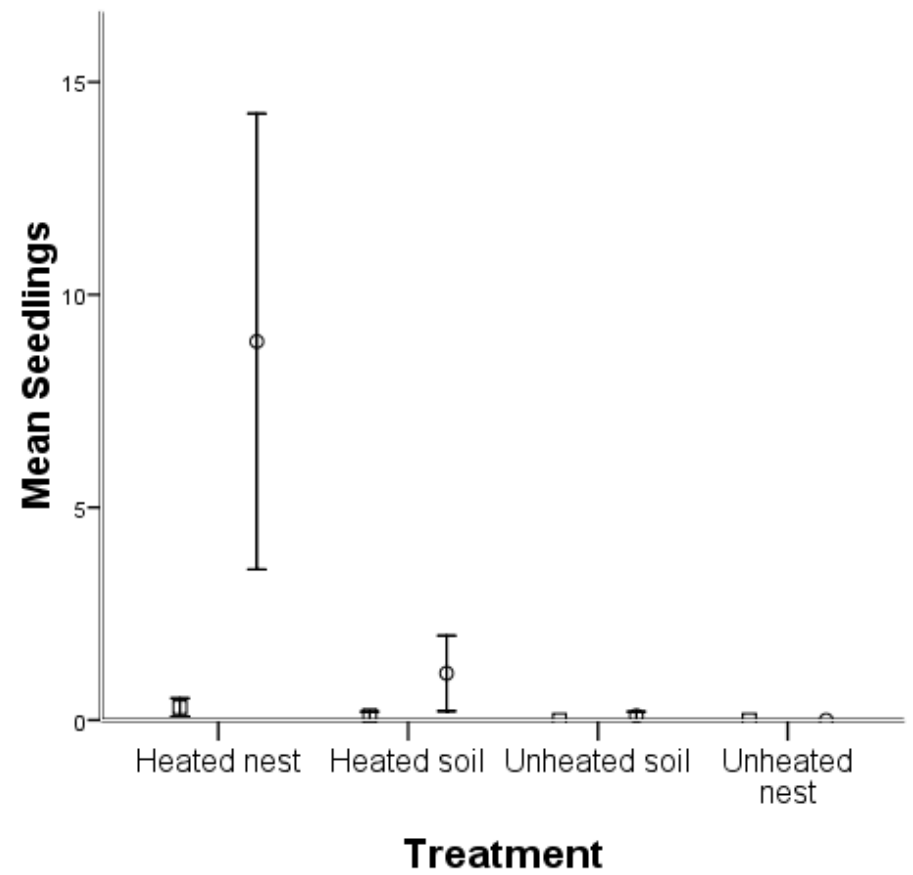

